\title{
WORK LIFE BALANCE AMONG HEALTHCARE WORKERS DURING COVID 19 WITH SPECIAL REFERENCE TO THALUK HEADQUARTERS HOSPITAL, NORTH PARAVUR, ERNAKULAM, KERALA
}

\author{
Rupini.T.S $\mathbf{S}^{1}$, Remya.S ${ }^{2}$ \\ Assistant Professor, St. Joseph's College (Autonomous), Irinjalakuda, Thrissur, Kerala ${ }^{1}$ \\ Assistant Professor, St. Joseph's College (Autonomous), Irinjalakuda, Thrissur, Kerala ${ }^{2}$
}

\begin{abstract}
Work Life balance is the equilibrium between personal and career life. Every person must give equal importance to both personal and professional life. Maintaining a proper work Life balance can reduce a lot of physical and mental issues. It has more positive effects like lower burnout, lesser stress, increase productivity etc. From the time of liberalization, privatization and globalization the work culture had made a drastic change. The employees are internally and externally challenged for performing well and devote their time for the work. Covid 19 is an infectious disease caused by newly discovered corona virus. The virus affects the respiratory organs so that the patients experience mild to moderate respiratory illness. Elder people having serious medical problems like diabetes, chronic respiratory disease, cardiovascular problems, fencers etc are more seriously affected. The extended working hours, repeated quarantines and inability to go home had made the situation more badly. The study is intended to analyse the various variables that affect the work-life balances among nurses during the COVID Pandemic.
\end{abstract}

Keywords-Covid 19, Work life balance

\section{INTRODUCTION}

Work-life balance is an employee's ability to maintain a healthy balance between their work roles, their personal responsibilities and family life. It is actually creating a boundary between the professional and personal life. The employees always prefer an employee friendly organisation which often leads to employee satisfaction. An individual plays multiple roles in his life. Imbalances in work life can cause conflicts. In today's age the role and responsibilities of employees both in professional and personal life has increased which often leads to personal and professional conflicts. Lack of proper balance between these two can cause stress related health problems. In addition to these conflicts, the results of pandemic had great severely affected work and personal life of employees. The spread of Novel corona virus had forced the world to work from home. The employees are often forced to work long hours than their actual working hours. The main challenge rises before them are to balance the work and family time. The whole world is trying to out beat the COVID-19 pandemic. The case of health care workers is very different. They are the frontline workers against the corona virus and they work day in and day out. Health care workers like Doctors, Nurses, Laboratory technicians, medical sanitary workers and are directly involved in the fight against COVID 19.

The extended working hours, repeated quarantines and inability to go home had made the situation more badly. The study is intended to analyse the various variables that affect the work-life balances among nurses during the COVID Pandemic. Statement of the problem

The study is conducted on topic 'WORK-LIFE BALANCE AMONG HEALTHCARE WORKERS DURING COVID19 WITH SPECIAL REFERENCE TO THALUK HEADQUARTERS HOSPITAL, NORTH PARAVUR'. This study also helps in understand the problems faced by healthcare workers in order to balance their work and personal life. It also give emphasis on the factors affecting work-life balance during COVID-19.The study also help in suggesting appropriate measures to improve the work life balance.

Significance of the study

Work-life balance among healthcare workers during COVID-19 is a topic of utmost importance in this era of pandemic. The whole world was trying to outbeat the novel coronavirus through social distancing, lockdown, quarantine period, work from home etc. The study of work-life balance helps in identifying the problems faced by healthcare workers during 


\section{International Advanced Research Journal in Science, Engineering and Technology}

Vol. 8, Issue 7, July 2021

\section{DOI: 10.17148/IARJSET.2021.8706}

this pandemic period. Extended working hours and repeated quarantines had made a great influence in the personal life of healthcare workers. Though there is a steady decline in the number of positive cases, the workload among health workers, nurses, doctors and other staff in hospitals are still restless and stressful which may often lead to both physical and mental illness. The study also helps in knowing the challenges and concerns of healthcare workers while dealing with the patients.

\section{Scope of the study}

The study is limited to the healthcare workers of Thaluk Headquarters hospital, North Paravur. The study is to find out the factors affecting work life balance. Dependent variable is work life balance. Independent variables are working hour, quarantine period, repeated shifts etc.

\section{Objectives}

The objectives in the study can be enumerated as below:

To identify the factors affecting work-life balance.

To study the problems faced by healthcare workers during the COVID-19.

To suggest appropriate measures to improve the work-life balance of healthcare workers.

\section{Research methodology}

Both primary and secondary data were used for the study. The primary data were collected by conducting interview and distributing questionnaires with the help of Google forms among healthcare workers. Secondary data were collected from published sources like journals, articles and websites. Population of the study is limited to the healthcare workers of Thaluk Headquarters Hospital, North Paravur. Sample sizes of 50 were taken. Sampling units chosen are the healthcare workers including nurses, doctors and others. Sampling technique used is non-probability sampling. Sampling method used is judgment sampling.

\section{Data analysis}

Testing independence of gender and ability to maintain work life balance

H0: There is no association between gender and ability to maintain WLB

H1: There is association between gender and ability to maintain Work Life Balance

\section{Association between gender and ability to maintain work life balance}

\begin{tabular}{|l|c|c|c|}
\hline PARTICULARS & $\begin{array}{c}\text { ABLE TO } \\
\text { MAINTAIN } \\
\text { WLB }\end{array}$ & $\begin{array}{c}\text { NOT ABLE } \\
\text { TO } \\
\text { MAINTAIN } \\
\text { WLB }\end{array}$ & TOTAL \\
\hline MALE & 11 & 6 & 17 \\
\hline FEMALE & 13 & 20 & 33 \\
\hline TOTAL & 24 & 26 & 50 \\
\hline
\end{tabular}

\begin{tabular}{|c|c|c|c|}
\hline $\begin{array}{l}\text { OBSERVED } \\
\text { FREQUENCY }\end{array}$ & $\begin{array}{l}\text { EXPECTED } \\
\text { FREQUENCY }\end{array}$ & $(\mathrm{O}-\mathrm{E})^{\wedge} 2$ & $(\mathrm{O}-\mathrm{E})^{\wedge} 2 / \mathrm{E}$ \\
\hline 11 & 8.16 & 8.0656 & 0.9884 \\
\hline 13 & 15.84 & 8.0656 & 0.5091 \\
\hline 6 & 8.84 & 8.0656 & 0.9123 \\
\hline 20 & 17.16 & 8.0656 & 0.4700 \\
\hline \multicolumn{3}{|c|}{ TOTAL } & 2.8798 \\
\hline
\end{tabular}

Calculation of chi-square value

Degree of freedom $=(r-1)(c-1)=(2-1)(2-1)=1 * 1=1$

Level of significance $=0.05$

Table value $=3.841$

Calculated value is less than table value, so we accept the null hypothesis. It means that there's no significant relationship between gender and ability to maintain work life balance.

Factors influencing work life balance

\begin{tabular}{|l|l|l|l|l|l|l|l|l|}
\hline Factors & $\begin{array}{c}\text { Weight } \\
\text { (X) }\end{array}$ & $\begin{array}{l}\text { HA } \\
5\end{array}$ & $\begin{array}{l}\text { A } \\
\text { G } \\
4\end{array}$ & $\begin{array}{l}\text { IN } \\
3\end{array}$ & $\begin{array}{l}\text { D } \\
2\end{array}$ & $\begin{array}{l}\text { H } \\
\text { D } \\
1\end{array}$ & $\begin{array}{l}\text { TOT } \\
\text { AL } \\
\text { SCO } \\
\text { RE }\end{array}$ & $\begin{array}{l}\text { MEAN } \\
\text { SCORE }\end{array}$ \\
\hline & F & 1 & 24 & 21 & 4 & 0 & & \\
\hline
\end{tabular}


International Advanced Research Journal in Science, Engineering and Technology

Vol. 8, Issue 7, July 2021

DOI: $10.17148 /$ IARJSET.2021.8706

\begin{tabular}{|l|l|l|l|l|l|l|l|l|}
\hline $\begin{array}{l}\text { REPEATED } \\
\text { QUARANTI } \\
\text { NE }\end{array}$ & FX & 5 & 96 & 63 & 8 & 0 & 172 & 3.44 \\
\hline $\begin{array}{l}\text { EXTENDED } \\
\text { WORKING } \\
\text { HOUR }\end{array}$ & $\mathrm{F}$ & 12 & 25 & 12 & 1 & 0 & & \\
\cline { 2 - 9 } FX & $\mathrm{F}$ & 13 & 21 & 9 & 5 & 2 & & \\
\hline $\begin{array}{l}\text { FEAR TO } \\
\text { CARRYING } \\
\text { VIRUS } \\
\text { HOME }\end{array}$ & $\mathrm{FX}$ & 65 & 84 & 27 & 10 & 2 & 188 & 3.76 \\
\hline $\begin{array}{l}\text { REPEATED } \\
\text { SHIFTS }\end{array}$ & $\mathrm{F}$ & 2 & 27 & 19 & 1 & 1 & & \\
\cline { 2 - 9 } & $\mathrm{FX}$ & 10 & 10 & 57 & 2 & 1 & 178 & 3.56 \\
\hline OTHERS & $\mathrm{F}$ & 1 & 2 & 44 & 2 & 1 & & \\
\cline { 2 - 9 } & $\mathrm{FX}$ & 5 & 8 & 13 & 4 & 1 & 150 & 3 \\
\hline
\end{tabular}

Overall satisfaction of healthcare workers

\begin{tabular}{|c|c|c|c|c|c|c|c|c|}
\hline & $\begin{array}{l}\text { WEIGHT } \\
\text { (X) }\end{array}$ & $5^{\mathrm{HS}}$ & $\begin{array}{l}S \\
4\end{array}$ & $\mathrm{IN}_{3}$ & $\begin{array}{l}\mathrm{D} \\
2\end{array}$ & $\begin{array}{c}\text { HD } \\
1\end{array}$ & $\begin{array}{l}\text { TOTAL } \\
\text { SCORE }\end{array}$ & $\begin{array}{l}\text { WEIGH } \\
\text { TED } \\
\text { MEAN }\end{array}$ \\
\hline \multirow{2}{*}{$\begin{array}{c}\text { DUTY } \\
\text { DURATION }\end{array}$} & $\mathrm{F}$ & 8 & 17 & 15 & 6 & 4 & & \\
\hline & $\mathrm{FX}$ & 40 & 68 & 45 & 12 & 4 & 169 & 3.38 \\
\hline \multirow{2}{*}{$\begin{array}{c}\text { AVAILABILITY } \\
\text { OF SAFETY } \\
\text { EQUIPMENT }\end{array}$} & $\mathrm{F}$ & 4 & 29 & 17 & 0 & 0 & & \\
\hline & $\mathrm{FX}$ & 20 & 116 & 51 & 0 & 0 & 187 & 3.74 \\
\hline \multirow{2}{*}{$\begin{array}{l}\text { AVAILABILITY } \\
\text { OF } \\
\text { QUARANTINE } \\
\text { PERIOD }\end{array}$} & $\mathrm{F}$ & 3 & 17 & 21 & 7 & 2 & & \\
\hline & $\mathrm{FX}$ & 15 & 68 & 63 & 14 & 2 & 162 & 3.24 \\
\hline \multirow[t]{2}{*}{$\begin{array}{l}\text { BEHAVIOUR OF } \\
\text { COLLEAGUES }\end{array}$} & $\mathrm{F}$ & 19 & 15 & 11 & 3 & 2 & & \\
\hline & $\mathrm{FX}$ & 95 & 60 & 33 & 6 & 2 & 196 & 3.92 \\
\hline \multirow{2}{*}{$\begin{array}{c}\text { BEHAVIOUR OF } \\
\text { FAMILY } \\
\text { MEMBERS }\end{array}$} & $\mathrm{F}$ & 16 & 27 & 7 & 0 & 0 & & \\
\hline & $\mathrm{FX}$ & 80 & 108 & 21 & 0 & 0 & 209 & 4.18 \\
\hline \multirow{2}{*}{$\begin{array}{c}\text { SERVICE } \\
\text { PROVIDED BY } \\
\text { YOU }\end{array}$} & $\mathrm{F}$ & 21 & 16 & 12 & 1 & 0 & & \\
\hline & $\mathrm{FX}$ & 105 & 64 & 36 & 2 & 0 & 207 & 4.14 \\
\hline \multirow{2}{*}{$\begin{array}{c}\text { SERVICE } \\
\text { PROVIDED TO } \\
\text { YOU } \\
\end{array}$} & $\mathrm{F}$ & 10 & 15 & 21 & 4 & 0 & & \\
\hline & FX & 50 & 60 & 63 & 8 & 0 & 181 & 3.62 \\
\hline
\end{tabular}

Problems faced by healthcare workers

\begin{tabular}{|l|l|l|l|l|l|l|l|l|l|}
\hline & $\begin{array}{l}\text { WEIGHT } \\
(\mathrm{X})\end{array}$ & 5 & 4 & 3 & 2 & 1 & TOTAL & $\begin{array}{l}\text { WEIGHTED } \\
\text { MEAN }\end{array}$ & RANK \\
\hline STRESS & $\mathrm{F}$ & 5 & 7 & 25 & 9 & 4 & 50 & & \\
\hline
\end{tabular}


International Advanced Research Journal in Science, Engineering and Technology

Vol. 8, Issue 7, July 2021

DOI: 10.17148/IARJSET.2021.8706

\begin{tabular}{|l|l|l|l|l|l|l|l|l|l|}
\hline & FX & 25 & 28 & 75 & 18 & 4 & 150 & 3 & 3 \\
\hline \multirow{2}{*}{ TIREDNESS } & F & 31 & 17 & 1 & 1 & 0 & 50 & & \\
\cline { 2 - 11 } & FX & 155 & 68 & 3 & 2 & 0 & 228 & 4.56 & 1 \\
\hline $\begin{array}{l}\text { HEALTH } \\
\text { ISSUES }\end{array}$ & F & 8 & 17 & 12 & 6 & 7 & 50 & & \\
\cline { 2 - 11 } & FX & 40 & 68 & 36 & 12 & 7 & 163 & 3.26 & 2 \\
\hline $\begin{array}{l}\text { INSUFFICIENT } \\
\text { EQUIPMENTS }\end{array}$ & F & 5 & 6 & 3 & 19 & 17 & 50 & & \\
\cline { 2 - 11 } & FX & 25 & 24 & 9 & 38 & 17 & 113 & 2.26 & 4 \\
\hline \multirow{2}{*}{ OTHERS } & FX & 1 & 3 & 9 & 15 & 22 & 50 & & 5 \\
\cline { 2 - 10 } & FX & 5 & 12 & 27 & 30 & 22 & 96 & 1.92 & \\
\hline
\end{tabular}

\section{Measures to improve work life balance}

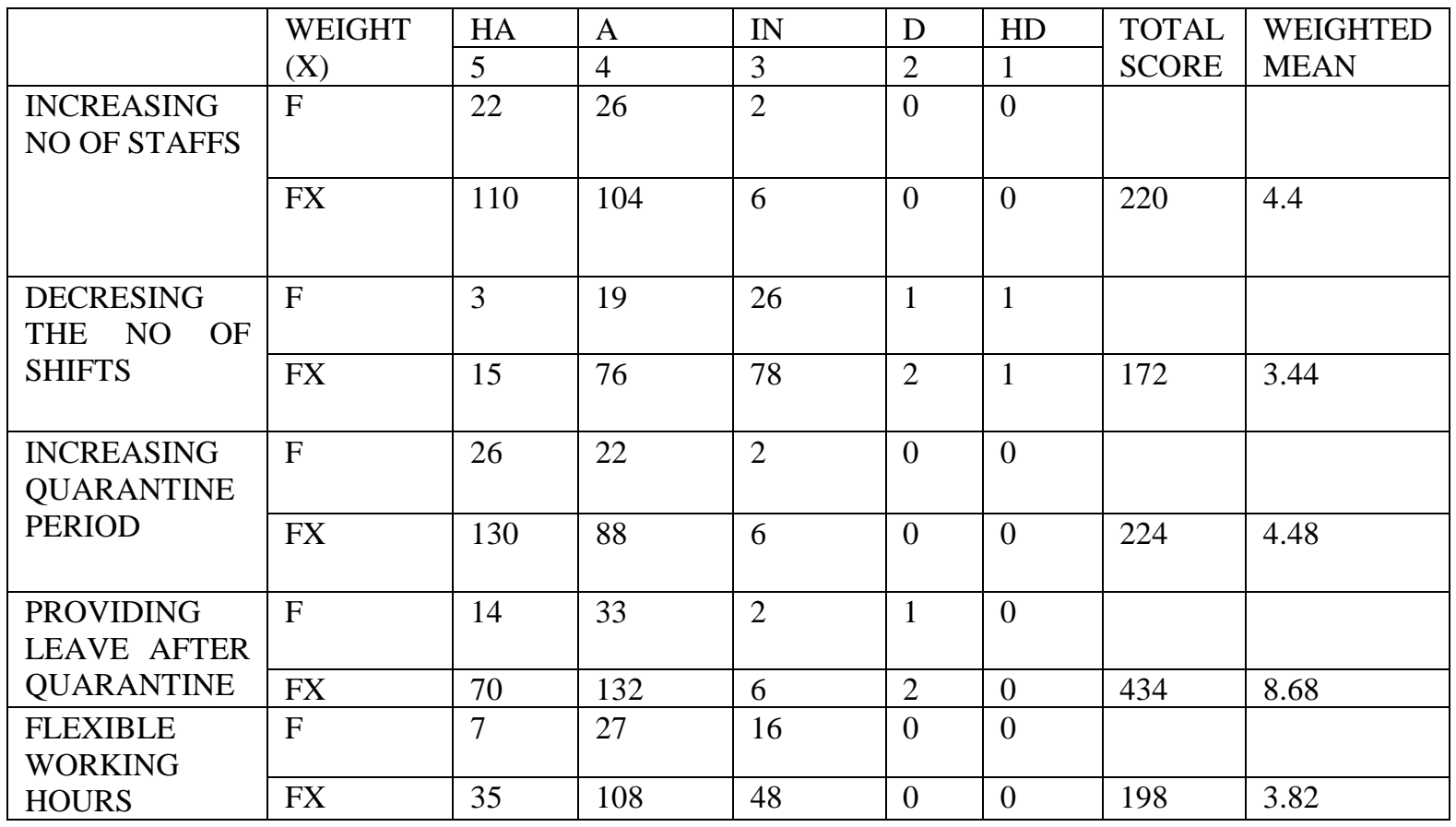

\section{FINDINGS}

- $66 \%$ of the respondents are female and $34 \%$ of the respondents are male.

- $50 \%$ of the respondents belong to age group of above 40 and $14 \%$ of the respondents belong to the age group below 30 .

- $\quad 48 \%$ of the respondents belongs to the category others. $6 \%$ of the respondents are doctors.

- $\quad 88 \%$ of the respondents are married and $12 \%$ of the respondents are unmarried.

- $\quad 92 \%$ of the respondents belong to nuclear family and $8 \%$ belong to joint family.

- $\quad 94 \%$ of the respondents had got COVID duty and $6 \%$ of the respondents were not assigned COVID duty.

- $72 \%$ of the respondents are of the opinion that their duty time affects family time only sometimes.20\% are of opinion that their duty time affects family time occasionally.4\% of the respondents says that their duty time 


\section{International Advanced Research Journal in Science, Engineering and Technology}

Vol. 8, Issue 7, July 2021

\section{DOI: 10.17148/IARJSET.2021.8706}

affects the family time rarely and the balance $4 \%$ responds that their duty never affects their family time. Nobody feels that the duty time affects the family time frequently.

- $38 \%$ of the respondents agree that increasing the number of staffs in COVID center can improve the duty time. $8 \%$ of respondents strongly agree with the statements.

- $64 \%$ of the respondents are of opinion that the safety equipments provided are of good quality and $30 \%$ says the equipments are of acceptable quality. $6 \%$ of the respondents says the safety equipments provided are of very good quality.

- $\quad 72 \%$ of respondents feel uncomfortable when working with these safety equipments. $4 \%$ feel indifferent and nobody feels highly comfortable while using these safety equipments

- $52 \%$ of the respondents are not able to maintain work life balance and $48 \%$ of the respondents are able to maintain work life balance.

- Chi Square test shows that there is no significant relationship between gender and ability to maintain work life balance.

- Among the factors mentioned extended working hours is the most influencing factor of work life balance. The least preferred are repeated quarantines and others.

- $62 \%$ of the respondents family members are supportive and $4 \%$ of the family members feel indifferent attitude.

- $\quad 94 \%$ of the respondents say that support from colleagues always helps in maintaining a proper work life balance. $2 \%$ of the respondents feel that support from colleagues often helps in maintaining a proper work life balance.

- $68 \%$ of the respondents are satisfied with the behavior of colleagues and $10 \%$ feel dissatisfied.

- $42 \%$ of the respondents feel neutral about the services provided to them.

- Among the mentioned factors for understanding the level of satisfaction the most preferred is support from family members followed by service provided by them. The least preferred is quarantine periods.

- Among the various problems tiredness is the most important problem faced by the respondents.

- $\quad$ Providing leave after quarantine period is preferred as the measure to improve proper work life balance.

- $74 \%$ of the respondents are satisfied with their professional life when compared to their personal life and $10 \%$ of the respondents feel indifferent.

\section{SUGGESTIONS}

- $\quad$ Reducing the working hour may help in maintaining a proper work life balance.

- Increasing the number of staffs in the covid care centers helps in reducing the tiredness among healthcare workers.

- Leave after quarantine period can be provided so that a proper work and life can be maintained.

- Quarantine facilities can be provided within the hospital so that life of family members are not compromised.

- Safety equipment of comfortable material can be provided.

- Government must take needed steps to honour all the staffs in the healthcare department for sacrificing their family life and even risking their own life.

- Monetary benefits like increments can be provided to the healthcare workers on COVID duty.

\section{CONCLUSION}

For an individual both personal and professional life are equally important. A better profession always helps in attaining a happy personal life and thereby a good societal life. During this pandemic era the things had changed forcing the men to be in his home seeking safety for the society and for himself. The healthcare workers had played a very crucial role in bringing the number of COVID cases down, risking their own life. The study is found important because it tries to know the factors that affect a proper work life balance of healthcare workers during the COVID pandemic.Achieving a proper work life balance is a growing concern for this pandemic world. Support from family and colleagues are equally important for maintaining a proper work life balance. From the study it is clear that the healthcare workers are not able to maintain a proper work life balance during COVID 19. When compared to their personal life they are satisfied with their professional life.

\section{REFERENCES}

1. R S V Rama swathi and A K Das Mohapatra, "Work life balance: Evolution and models -A study in the indian context", International journal of political research, Volume 6, No:5, 2017, 1910-1914

2. Thomas Kalliyath and Paula Brough "Work life balance: A review of meaning of the balance constructed", Journal of management and organisation, volume 14, No 3,2008,pp:323-327

3. Prabhashani R M B and Rathnayak R M "Determinants of work life balance among nurses: Empirical evidence from Monregela district general hospital,Srilanka",6th International conference on Management and Economics,2017/ISBN: 978-955-1507-56-5

4. Tarika Sharma "Work life balance in Covid time", Journal of perioperative and critical intensive care nursing, volume 1,No 151,2002 


\title{
International Advanced Research Journal in Science, Engineering and Technology
}

\author{
Vol. 8, Issue 7, July 2021
}

\section{DOI: 10.17148/IARJSET.2021.8706}

5. T Alexandra Beuregard and Lesley H Henry "making the link between work life balance practices and organisational performance", Human Resource Management Review, No 19,pp:22

6. Ipseeta Satpathy, B Chandra Mohan Patnaik and Susmita Jena " A comparative study on work life balance of nursing staff working in private and government hospital", International journal of innovative research in science, engineering and technology, volume 3,no 1,2014

7. C Ramesh kumar and R Ramani "Work life balance of women doctors in kanyakumari district", International journal of management studies, volume 5,No 4,pp:8

8. Bindiya Goyal "Work life balance of nurses and lady doctors", International journal of Management research, volume4, No 4,2014,pp:244-249

9. Anupam Verma; Vandana Srivastava. "Natural Resource Consumption and Lockdown". International Research Journal on Advanced Science Hub, 2, 6, 2020, 79-86. doi: 10.47392/irjash.2020.41

10. M Jensirani and A Muthumani "A study on work life balance of nurses in kovilpatti town", International journal of science ,Technology and Management, volume 5,No 2,017,pp:114-121

11. G Suguna and Eugine Franco " A study on work life balance of nursing staff working in private hospitals in palayamkottai",International Journal of research-Granthalayah, volume 5,no 8,2017,pp:106-109

12. R Ramakrishnan" work life balance in post covid 19", Journal of management and organisation, volume 14,no 3,2020,pp:323-327

13. Aditi Joshi and Shivani Gour" A study of work life balance during COVID 19",Journal of critical reviews, volume 7,No 11,2020,pp:4149-4146

14. Antony Carla S.; Sumathi M.. "Maximum lifespan prediction of women from Modified Weibull Distribution". International Research Journal on Advanced Science Hub, 3, 3, 2021, 56-60. doi: 10.47392/irjash.2021.097

15. P Varanasi and S Ahmed"Factors affecting work life balance of medical proffessionals",Recent advances on economics and Business administration, volume ,no ,pp:61-65 A Sharmila and C Vethirajan" Stress and work life balance among women employees in government hospitals during COVID 19", International Journal of Innovative Research in Technology, volume7,no 5, 2020,pp 104-111

16. Chaitra c, Ashok Kumar R S and T P Renuka Murthy” A study on work life balance of employees at Bosch ltd, Banglore" ,BIMS International Journal of Social Science Research, volume 1, no 2, 2016,61-68

17. Sachiko Makabe, Junko Takagai and Yutaka Kimora" Impact of work life imbalances on job satisfaction and quality of life among hospital nurses in japan", Industrial health,2015, DOI 10.2486/indhealth.2014,pp152-159

18. Remya S. "Covid19 and Environment-A Theoretical Review from Higher Education Students Perspective". International Research Journal on Advanced Science Hub, 2, Special Issue ICARD 2020, 2020, 227-230. doi: 10.47392/irjash.2020.124

19. Lavanya B.; Divya Sree B.. "Work-life Balance and Organizational Citizenship Behaviour-A study with reference to Bank Employees". International Research Journal on Advanced Science Hub, 3, Special Issue ICSTM-2021 6S, $2021,29-36$.

20. Muniyandy Elangovan; Ravichandran A T; Prabhukumar Chellamuthu. "Need of Energy Audit in Everyday Life". International Research Journal on Advanced Science Hub, 2, 11, 2020, 6-11. doi: 10.47392/irjash.2020.212

\section{Websites}

1. https://www.kumanu.com

2. https://www.who.int

3. https://covid19.who.int

4. https://www.investindia.gov.in

5. https://kerala.gov.in 